61 巻 581 号 $(1995-1)$

\title{
磁性流体によって駆動される円管内液柱の運動*
}

\author{
小池 和 雄 ${ }^{* 1}$, 後 藤 聡*2, 佐 藤 彰*1
}

\section{Motion of Liquid Column Driven by Magnetic Fluid in a Circular Tube}

\author{
Kazuo KOIKE, Satoshi GOTO and Akira SATO
}

\begin{abstract}
The motion of a liquid column in a circular tube, driven by the motion of a magnetic fluid under an oscillating magnetic field in the axial direction, is studied experimentally. Nondiluted hydrocarbonbased magnetic fluid and a kind of fluorocarbon are employed as working fluids. The displacement of the magnetic fluid column becomes larger than that reported in the previous work. However, the magnetic fluid column is separated from the driven liquid at the interface in the frequency range where the displacement is expected to increase. For a U-tube of constant diameter, the time variation of displacement shows a distorted waveform in the lower frequency range due to smaller hydraulic loss, although the displacement is considerably large even in the case of rather weak input current to the solenoid. Numerical analyses are also carried out using conditions similar to those of the experiments. The predicted results agree well with experimental data in the case of no separation at the interface.
\end{abstract}

Key Words: Magnetic Fluid, Pipe Flow, Oscillatory Flow, Flow Control, Numerical Analysis, Viscous Flow

\section{1. 緒 言}

磁場下での磁体流体は，流体自身が磁化することに より磁気体積力の作用を受け，磁場に応答していくつ かの興味ある挙動を示す.このような磁気的な機能を 有する流体としての特質から，磁性流体はさまざまな 分野で関心を集めており，軸シールや軸受など磁性流 体を磁気力によって保持した応用機器の実用化,さら には新しい応用機器開発のための基礎研究が行われて きている(1)(2).

一方，磁場下での磁性流体に作用する磁気力は，磁 場の強さや分布を変化させることによっても変えるこ とができ, 例えば変動磁場を印加して磁性流体液柱に 往復動を誘起させることもできる( ${ }^{(3) \sim(5)}$.このような特 性に着目して，著者らはこれまで印加する磁場強さを 変えることにより誘起される磁性流体液柱の運動を, 流体運動の駆動源として応用するための基礎研究を行 ってきた ${ }^{(6) \sim(8)}$.これらの研究では, 管径の異なる円管 からなるモデル管を用い，管路抵抗などの影響も含め た変動磁場下での液柱運動の特性についておもに検討

* 原稿受付 平成 6 年 4 月 19 日.

*1 正員, 東北学院大学工学部 ( 6985 多賀城市中央 1-13-1).

*2 学生員, 東北学院大学大学院.
を行った。また，磁性流体液柱の運動を外部に伝達す る場合には，より低粘度の液体を用いるのが効果的で あると考えられることから, 被駆動液体部分には蒸留 水を用い，磁性流体をこれよりも密度が低くなるよう に希釈して用いてきた.

本研究ではこれまでの研究をさらに進展させ，より 大きな磁気力の変化が得られるように磁性流体を希釈 せずに原液のまま用い, 被駆動液体部分にはこれより も密度が高く粘度の低い液体を用いて，これまでと同 様なモデル管内での液柱運動の特性について検討を行 った.さらに, 装置の小形化と省電力化の観点から, 磁 性流体液柱に磁場を印加するソレノイドを小形化し， 内径が一様で管断面積の変化に基づく損失を考慮する 必要のない $U$ 字管内での特性についても検討を行っ た。

\section{おもな 鱾 号}

$$
\begin{aligned}
A_{\mathrm{p}-\mathrm{p}} & : \text { 変位全振幅 } \\
B & : \text { 磁束密度 } \\
d & : \text { 円管内径 } \\
f & : \text { 振動数 } \\
g & : \text { 重力の加速度 } \\
H & : \text { 磁場の強さ }
\end{aligned}
$$


$i:$ ソノイドへの供給電流

$I:$ 磁化の強さ

$K:$ ディーン数 $=\operatorname{Re}\{d /(2 R)\}^{1 / 2}$

$l:$ 夜柱の長さ

$p:$ 圧力

$R:$ 管中心軸の曲率半径

$R e:$

$T:$ 液温

$v:$ 流速

Wo: ウォマスリ数 $=(d / 2)(2 \pi f / \nu)^{1 / 2}$

$z_{20}$ ：磁場中心加らの磁性流体液柱上端初期高さ

$\delta:$ 位相差

$\zeta:$ 損失係数

$\eta:$ 粘度

$\theta:$ 接触角

$\lambda:$ 管摩擦係数

$\nu:$ 動粘度

$\rho:$ 密度

$\sigma$ :界面張力

添字

0 ：非磁性流体液柱の上端(開放側)

1：磁性流体と非磁性流体の界面

$2:$ 磁性流体液柱の上端

$f:$ 非磁性流体

$m:$ 磁性流体

$n:$ 細管部

$w ：$ 主管部

\section{2. 实験装亚および方法}

磁性流体液柱の運動を流体運動の駆動源として応用 するためには，幅広い流動条件下での特性を知る必要 があることからこれまで管断面積の異なる管からな るモデル管を用いて検討を行ってきた，本報では，ま ず既報 ${ }^{(6) \sim(8)}$ と同様に，図 1 (a)に概略を示すような, 下端が閉じられ上端が開放された内径 $d_{w}$ の 2 本の円 管 (主管部)とその下部でこれらを連結する内径 $d_{n}$ の 細管からなるモデル管を用いて検討を行った，また， 駆動源としての磁性流体には炭化水素ベース磁性流体 (フェリコロイド $\mathrm{HC}-50,25^{\circ} \mathrm{C} て ゙ \nu=12.8 \mathrm{~mm}^{2} / \mathrm{s}$, $\left.\zeta=1390 \mathrm{~kg} / \mathrm{m}^{3}, \sigma=26 \mathrm{mN} / \mathrm{m}\right)$ を希釈せずに用い, 被駆動液体には予備実験からこれと最もよい組合せと なると考えられた HC-50よりも密度が高くて粘度が 低いふつ素系不活性液体(フロリナート $\mathrm{FC}-40,25^{\circ} \mathrm{C}$, で $\left.\nu=2.2 \mathrm{~mm}^{2} / \mathrm{s}, \zeta=1870 \mathrm{~kg} / \mathrm{m}^{3}, \sigma=16 \mathrm{mN} / \mathrm{m}\right)$ を 用いた，実験手順は既報 ${ }^{(6) \sim(8)}$ と同様であり，モデル管 内に主管部の合計長さ $l_{f}\left(=l_{f 1}+l_{f 2}\right)$ の FC-40 と片方

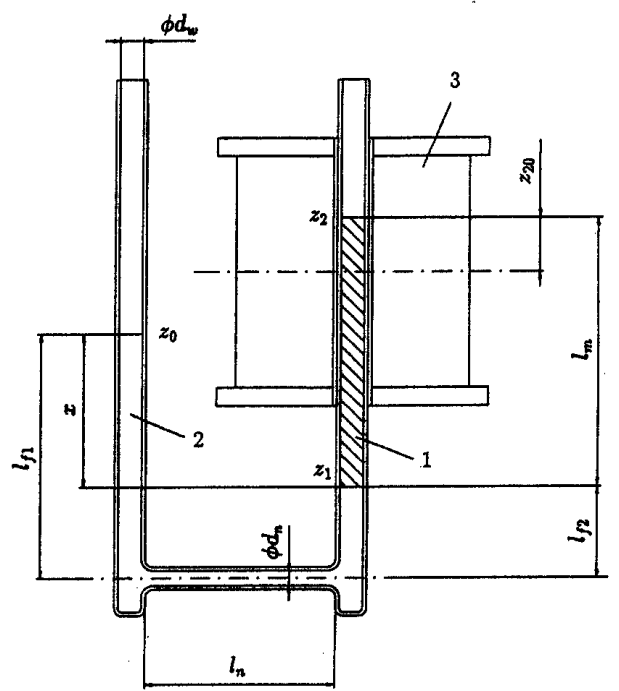

$l_{f}=l_{f 1}+l_{f 2}$

(a)

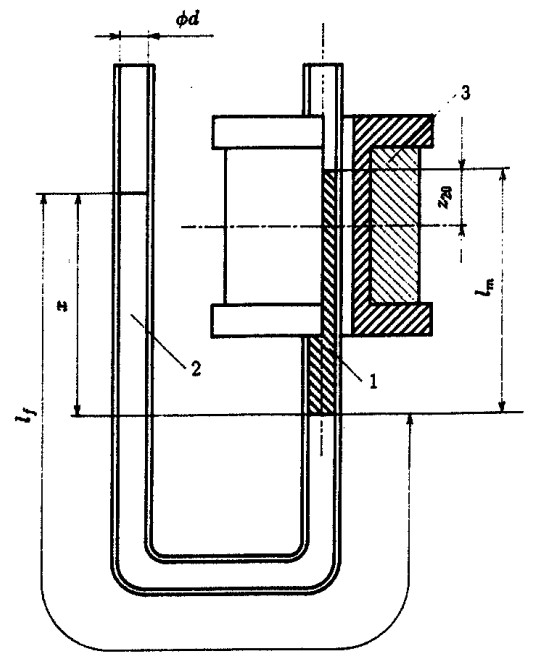

1. Magnetic Fluid, 2. Non-magnetic Fluid, 3. Solenoid

(b)

図 1 モデル管の概略

の主管の FC-40の上に長さ $l_{m}$ の HC-50を入れた, 次 に，HC-50の入った主管側に設置したソレノイドに， $i_{o}[\mathrm{~A}]$ のオフセット電流を流すことにより軸方向定常 磁場を発生させて磁性流体液柱を保持し, ソレノイド 中心から磁性流体液柱上端までの距離 $z_{20}$ が設定值に なるようにモデル管の位置を調節した。.さらに， $i_{o} に$ 所定の振動数 $f$ で振幅 $\Delta i[\mathrm{~A}]$ の正弦波状または方形 波状の変動電流を付加して変動磁場を発生させ, 液柱 の運動を誘起した，このときのソレノイドへの供給電 流 $i$ は次式で表される.

$$
i=i_{o}+\Delta i g(f t)
$$




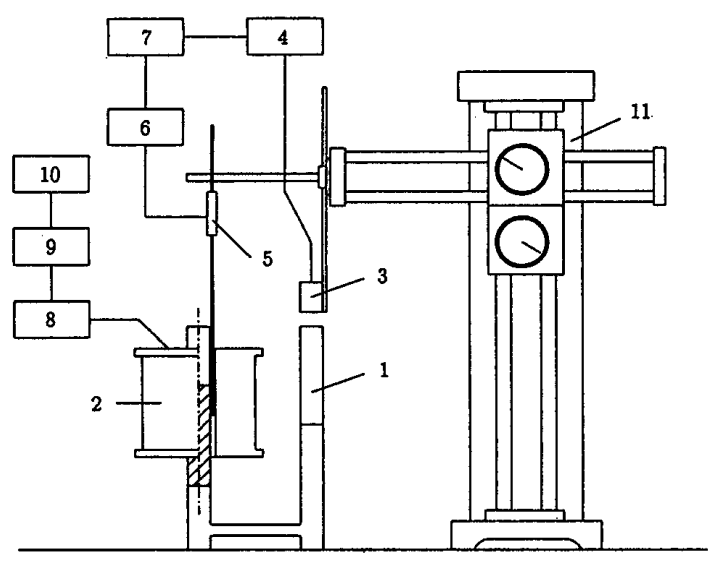

1. Test Pipe, 2. Solenoid, 3. Ultrasonic Displacement Sensor, 4. Controller, 5. Axial Probe, 6. Gaussmeter, 7. Waveform Analyzer, 8. Ammeter, 9. Power Supply, 10. Function Generator, 11. Coordinate Measuring Machine

図 2 測定系の概略

\section{$i_{o}:$ オヤット電流 \\ $\Delta i:$ 変動電流の振幅}

$g(f t)$ : 正弦波状の場合, $g(f t)=\sin 2 \pi f t$

方形波状の場合,

$n<f t<(n+1 / 2) \quad$ で $g(f t)=1.0$

$f t=n / 2 \quad$ で $g(f t)=0$

$(n+1 / 2)<f t<(n+1) \quad$ で $g(f t)=-1.0$

さらに, 図 $1(\mathrm{~b})$ に概略を示すような内径が一様な U 字管についても同様な手順で実験を行った。なお, この場合には液柱長さの短縮化や管路の小形化も念頭 に入れ，新たに製作した小形のソレノイドを用いた。

図 2 には測定システムの概略を示す. 液柱の変位は, 磁性流体が入っていない側の主管の上方に設置した超 音波変位センサにより液面の位置を検知し, 超音波変 位計を介した信号を波形解析装置に入力して, 定常状 態に達した後の表示波形から求めた。 また, 磁束密度 の変化については，基準位置に設置した測定端子から の信号をガウスメータを介して波形解析装置に入力 し, 変動波形がソレノイドに供給される変動電流の波 形と同様であることや，振幅が振動数によらず一定で あることを確認し, 同時に波柱変位との位相差 $\delta$ を求 めた。

\section{3. 理論的考察}

図 1 (a) のモデル管内の液柱運動の特性を理論的に 求めるため, 実験と同様な解析モデルを考える。管摩 擦損失や主管部から細管部および細管部から主管部へ 流れる際の流入および流出損失などの諸損失や管が細 くなった場合に重要性が増すと考えられる界面での張
力を考慮すると，モデル管内の液柱運動を支配する方 程式は次式のように表すことができる。

$$
\begin{aligned}
& {\left[\rho_{f}\left\{l_{f}+l_{n}\left(d_{w} / d_{n}\right)^{2}\right\}+\rho_{m} l_{m}\right] d v_{w} / d t} \\
& +\lambda_{w}\left(l_{w} / d_{w}\right) \rho_{f} v_{w}^{2} / 2+\lambda_{n}\left(l_{n} / d_{n}\right) \rho_{f} v_{n}^{2} / 2 \\
& +\lambda_{m}\left(l_{m} / d_{w}\right) \rho_{m} v_{w}^{2} / 2+\left(\zeta_{n w}+\zeta_{w n}+\zeta_{w}\right) \rho_{f} v_{w}^{2} / 2 \\
& +\zeta_{n} \rho_{f} v_{n}^{2} / 2+\zeta_{m} \rho_{m} v_{w}^{2} / 2 \\
& +\rho_{f} g(2 \Delta z-x)+\rho_{m} g l_{m}+p_{0}-p_{2} \\
& +\left(4 / d_{w}\right)\left(\sigma_{0} \cos \theta_{0}-\sigma_{1} \cos \theta_{1}-\sigma_{2} \cos \theta_{2}\right) \\
& -\int_{z_{1}}^{z_{2}} I\left(d H_{z} / d z\right) d z=0
\end{aligned}
$$

層流を仮定し，管摩擦係数入を層流の場合の式で置き 換え，さらに磁性流体部分での磁場の影響による見掛 け粘度の増加を考慮して, 補正係数 $C_{m}$ を導入した。 また, 主管部から細管部および細管部から主管部一流 れる際の流入および流出損失係数は, 変位の大きな領 域の $R_{w}\left(d_{w}\right.$ を代表長さとするレイノルズ数)に対応 する定常流の場合の予備実験結果に基づき， $\zeta_{f}=$ $C_{f 0} / R e_{w}\left[こ こ て, \zeta_{f}=\zeta_{n w}+\zeta_{w n}+\zeta_{w}+\left(d_{w} / d_{n}\right)^{4} \zeta_{n}\right] \tau$ 近似した。ささらに, 初期条件および速度と変位の関係 を用いて式の変形を行い, $\Delta z$ を $z$ で置き換えて表す と, 次式が得られる。

$d z^{2} / d t^{2}+\left\{\alpha_{1}^{\prime}+\alpha_{2}^{\prime}(d z / d t)\right\} d z / d t+\alpha_{3} z=F \cdots$ ここで,

$$
\begin{aligned}
\alpha_{1}^{\prime} & =\alpha_{1}+\left(1 / C_{1}\right)\left\{\eta_{f} C_{f 0} /\left(2 d_{w}\right)\right\}, \\
\alpha_{2}^{\prime} & =\left(1 / C_{1}\right) \rho_{m} \zeta_{m} / 2, \\
\alpha_{1} & =C_{2} / C_{1}, \alpha_{3}=2 \rho_{f} g / C_{1}, F=\left(F_{m}+F_{\sigma}\right) / C_{1} \\
F_{m} & =\int_{z_{1}}^{z_{2}} I\left(d H_{z} / d z\right) d z-\int_{z_{10}}^{z_{20}} I\left(d H_{2} / d z\right) d z \\
F_{\sigma} & =\left(4 / d_{w}\right)\left[\sigma_{00} \cos \theta_{00}\left\{1-\sigma_{0} \cos \theta_{0} /\left(\sigma_{00} \cos \theta_{00}\right)\right\}\right. \\
& -\sigma_{10} \cos \theta_{10}\left\{1-\sigma_{1} \cos \theta_{1} /\left(\sigma_{10} \cos \theta_{10}\right)\right\} \\
& \left.-\sigma_{20} \cos \theta_{20}\left\{1-\sigma_{2} \cos \theta_{2} /\left(\sigma_{20} \cos \theta_{20}\right)\right\}\right] \\
C_{1} & =\rho_{f}\left\{l_{f}+l_{n}\left(d_{w} / d_{n}\right)^{2}\right\}+\rho_{m} l_{m} \\
C_{2} & =\left(32 \eta_{f} / d_{w}^{2}\right)\left[\left\{l_{f}+\left(d_{w} / d_{n}\right)^{4} l_{n}\right\}+\left(\eta_{m} / \eta_{f}\right) C_{m} l_{m}\right]
\end{aligned}
$$

また, 内径が一様な U 字管の場合には, 被駆動液体 部分を直管部の長さ $l_{s}$, 曲がり管部の長さ $l_{c}$ (したが って, $\left.l_{f}=l_{s}+l_{c}\right)$ に分けて考えると，基礎方程式は次 式のように表すことができる.

$$
\begin{aligned}
& \left(\rho_{f} l_{f}+\rho_{m} l_{m}\right) d v / d t+\lambda_{s}\left(l_{s} / d\right) \rho_{f} v^{2} / 2 \\
& \quad+\lambda_{c}\left(l_{c} / d\right) \rho_{f} v^{2} / 2+\lambda_{m}\left(l_{m} / d\right) \rho_{m} v^{2} / 2 \\
& \quad+\rho_{f} g(2 \Delta z-x)+\rho_{m} g l_{m}+p_{0}-p_{2} \\
& \quad+\left(4 / d_{w}\right)\left(\sigma_{0} \cos \theta_{0}-\sigma_{1} \cos \theta_{1}-\sigma_{2} \cos \theta_{2}\right) \\
& \quad-\int_{z_{1}}^{z_{2}} I\left(d H_{z} / d z\right) d z=0
\end{aligned}
$$$$
\text { ここで, }
$$

$\lambda_{c}:$ 曲がり部での管摩擦係数

$\lambda_{s}:$ 直管部での管摩擦係数

前述のモデル管の場合と同様に層流を仮定し， $\lambda_{s}$ を層 
流の式で置き換える．また， $\lambda_{c}$ は $K<13.5$ では直管の 管摩摖係数に一致するものとし， $K \geqq 13.5$ の場合には 次式で補正した ${ }^{(9)}$ 。

$$
\lambda_{c} / \lambda_{s}=21.5 K /\left(1.56+\log _{10} K\right)^{5.73}
$$

前の場合と同様に初期条件等を用いて式の変形を行う と次式が得られる.

$$
d z^{2} / d t^{2}+\alpha_{4} d z / d t+\alpha_{5} z=F
$$

$$
\text { ここで, }
$$

$$
\begin{aligned}
& \alpha_{4}=C_{2}^{\prime} / C_{1}^{\prime}, \alpha_{5}=2 \rho_{f} g / C_{1}^{\prime}, F=\left(F_{m}+F_{\sigma}\right) / C_{1}^{\prime} \\
& C_{1}^{\prime}=\rho_{f} l_{f}+\rho_{m} l_{m} \\
& C_{2}^{\prime}=\left(32 \eta_{f} / d^{2}\right)\left[\left\{l_{s}+G(\nu) l_{c}\right\}+\left(\eta_{m} / \eta_{f}\right) C_{m} l_{m}\right] \\
& G(\nu)=21.5 K /\left(1.56+\log _{10} K\right)^{5.73}
\end{aligned}
$$

ソレノイドの磁場分析と磁場こう配は，既報(6) (8) と同様に測定值とのよい一致が得られた式(6)で近似 した。また，磁性流体の磁化の強さ $I$ もこれまでと同 様に磁性粒子の粒径が対数正規分布であると仮定した 式から求めた ${ }^{(10)}$.

計算では図 1 (a)のモデル管については式(3), 図 1（b)のU 字管については式(3)'をそれぞれの設定 条件の下で数值的に解き, 液面の変化や変動磁場と変 位との位相差などの諸量を求めた。

\section{4. 実験結果および数值計算との比較}

実験では主管の内径 $d_{w}$ が $10.7 \mathrm{~mm}$, 細管の内径 $d_{n}$ と長さ $l_{n}$ がそれぞれ $5.5 \mathrm{~mm}$ と $80 \mathrm{~mm}$ のモデル 管について，液柱長さ $l_{f}, l_{m}$ をそれぞれ $160,120 \mathrm{~mm}$

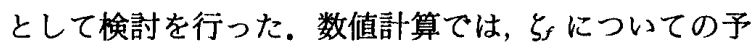
備実験結果に基づき $C_{f 0}=10000$ と仮定した。ささらに， $\alpha_{2}^{\prime}=0$ として式の線形化をはかり，計算時間を短縮さ せた。また, 界面張力については, 磁場下での変化を適 切に評価するデータが得られていないことや，今回測 定に用いた管の内径が $10.7 \mathrm{~mm}$ と比較的大きく，そ の影響が小さいと考えられることから，一定と仮定し て計算を行った。

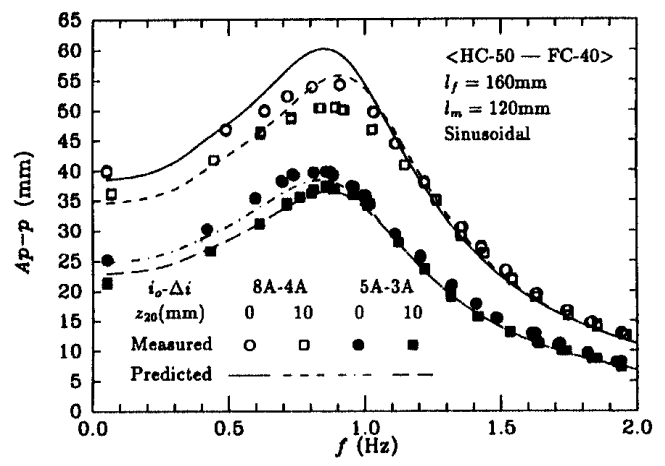

図 3 振動特性に及涩す磁場条件の影響
図 3 には結果の一例として,これまでの作動流体が $20 \mathrm{wt} \%$ のC-50 と蒸留水の場合 ${ }^{(6) \sim(8)}$ と同様に, ソ レノイドへの供給電流が $i_{o}=8 \mathrm{~A}, \Delta i=4 \mathrm{~A}$ の場合の 変動電流の振動数 $f$ に対する変位全振幅 $A_{p-p}$ の変化 の様相について, 磁性流体液柱上端の初期高さ $z_{20}$ が $0 \mathrm{~mm}$ と $10 \mathrm{~mm}$ で正弦波状変動磁場の場合の結果を 示す。この条件では作動流体が $20 \mathrm{wt} \%$ の HC-50 と蒸 留水の場合の結果に比へ $f$ の比較的高い領域では大 きな変位が得られた，しかしながら，より大きな変位 が得られると考えられる $f$ の領域で磁性流体部分が 被駆動液体との界面で被駆動液体と分離し，被駆動液 体部に磁性流体液柱の運動が効果的に伝達されなかっ た。この傾向は変位がより大きくなると考えられる $z_{20}=0 \mathrm{~mm}$ の場合のほうが䫓著であった. 図 3 中には これと対比するため, $i_{o}=8 \mathrm{~A}, \Delta i=4 \mathrm{~A}$ で作動流体が $20 \mathrm{wt} \%$ のC-50 と蒸留水の場合と同程度の $A_{p-p}$ が 得られた $i_{o}=5 \mathrm{~A}, \Delta i=3 \mathrm{~A}$ の場合の結果もあわせて 示した. 計算結果は, 磁性流体が被駆動液体と界面で 分離しなかった $i_{o}=5 \mathrm{~A}, \Delta i=3 \mathrm{~A}$ の場合には測定值と よく一致した。また， $i_{0}=8 \mathrm{~A}, \Delta i=4 \mathrm{~A}$ の場合でも界 面で分離しない領域では測定結果とよく一致した。

方形波状変動磁場の場合には $i_{o}=8 \mathrm{~A}, \Delta i=4 \mathrm{~A}$ の 印加磁場条件で界面で分離する領域はさらに広がる が, $f$ に対する $A_{p-p}$ の変化の様相については同様の 結果が得られた. 変動磁場波形の影響については, 予 想されたように方形波状の場合のほうが正弦波状の場 合に比べ大きな $A_{p-p}$ が得られた。しかしながら，変 位の時間変化波形は正弦波状の場合が一般に正弦曲線 に近い変化を示したのに対し，方形波状の場合には， 低い $f$ の領域でこれよりもひずみの大きな変位波形 を示した。

今回被駆動液体として用いた FC-40 は動粘度が, 従来の蒸留水に比べて 2 倍以上も高いことから, レイ ノルズ数 $R e_{w}$ も低くなる.ここでの測定結果から求め

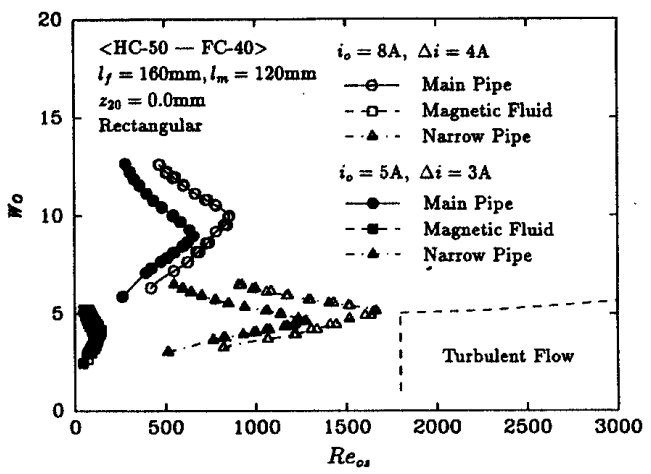

図 4 振動流のレイノルズ数 $R e_{o s}$ とウォマスリ数 $W o$ 
た振動流のレイノルズ数 $\operatorname{Re}_{o s}\left(=u_{o s} d / \nu: こ こ に\right.$, $u_{o s}$ : 管断面平均流速の振幅) とウォマスリ数 $W o$ の 領域は，振幅が最も大きな方形波状変動磁場で $z_{20}=0$ $\mathrm{mm}$ の場合でも図 4 に示されるように層流域内 ${ }^{(1)}$ に あった。しかしながら, 界面で分離せず運動がそのま ま伝達された場合には, $R e_{o s}$ が最も高い細管部では 乱流域にまで達し，抵抗も急増するものと考えられ る.したがって，これも液柱が分離する遠因となって いるものと考えられる.

図 5 には振動特性に及洣す $z_{20}$ の影響について, $i_{o}=5 \mathrm{~A}, \Delta i=3 \mathrm{~A}$ で方形波状変動磁場の場合の実験 結果を示す. 従来の被駆動液体として㸃留水を用いた 場合と同様に, $z_{20}$ が小さくなるにつれて $f$ の低い領 域では $A_{p-p}$ が大きくなり，その最大值も増加した。 しかしながら，磁性流体液柱上面の位置をさらに下げ て $z_{20}$ を-20 mm とした場合には, $f$ が低い領域の $A_{p-p}$ は大きくなるが, $A_{p-p}$ が最大となる $f$ の值は減 少した。また，印加磁場条件の振動特性に及ほす影響 について検討するため, $i_{o}$ を下げ, $\Delta i$ を上げて $i_{o}=4$ $\mathrm{A}, \Delta i=4 \mathrm{~A}$ とした場合の結果は, $i_{o}=5 \mathrm{~A}, \Delta i=3 \mathrm{~A}$ の場合に比べて大きな $A_{p-p}$ が得られた.

図 6 には定常磁場下での基準位置 $z_{20}$ に対する液面

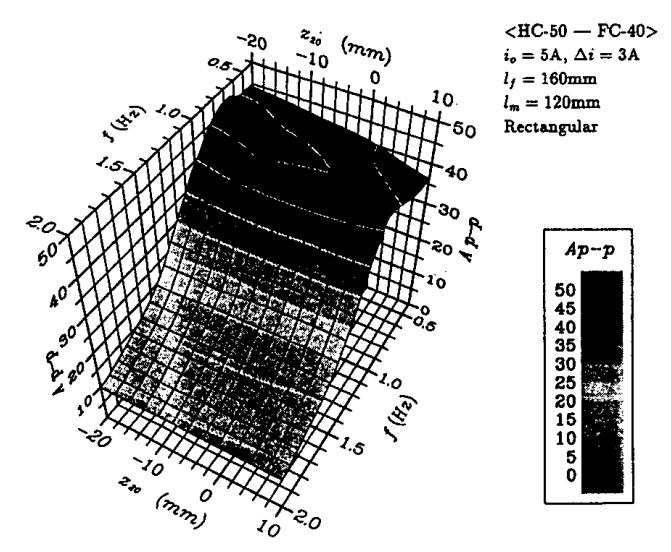

図 5 振動特性に及涩す $z_{20}$ の影響

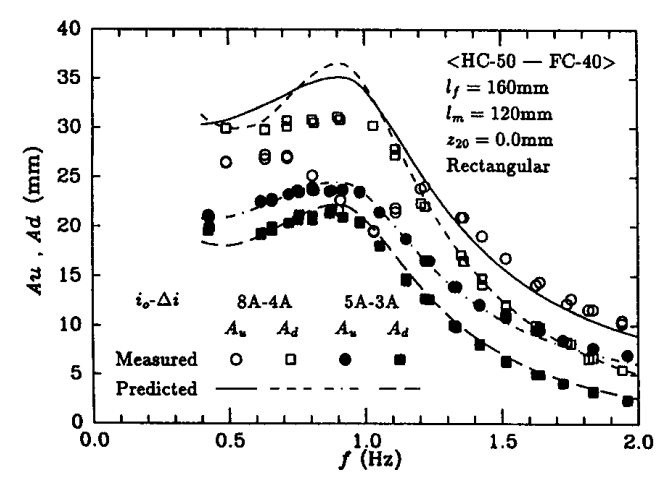

図 6 上下方向への変位
の上下方向への変位について， $z_{20}=0 \mathrm{~mm}$ で方形波状 変動磁場の場合の結果を示す.ここで, $A_{u}$ は磁場の増 加による $z_{20}$ からの上昇部分, $A_{d}$ は磁場の減少による 下降部分を示す. $i_{o}=5 \mathrm{~A}, \Delta i=3 \mathrm{~A}$ の場合には上下方 向への変位は対称とはならず, $A_{u}$ が $A_{d}$ よりもかな り大きいという結果が得られた．上下方向への変位に ついての従来の計算值は測定值とのよい一致が得られ なかったが, 図 6 中にも示されるように今回の計算結 果は測定值と非常によく一致した。また，この印加磁 場条件の場合には $z_{20}$ を変化させた場合に $A_{u}$ のほう が $A_{d}$ に比べて大きく変化した。 $i_{o}=8 \mathrm{~A}, \Delta i=4 \mathrm{~A}$ の 場合も境界が分離しない高い $f$ の領域では計算と測 定結果はよく一致した. より大きな変位が得られると 考元られた低い $f$ の領域では液柱が界面で分離した が, $A_{u}$ の測定結果は計算值よりかなり小さくなって おり，液柱が引き上げられる際に分離したことを示し ている.これに関連して, 液柱が引き上げられる際の 速度と加速度を計算から求めたが, 液柱の分離は速度 と密接に関連しており, $i_{o}=8 \mathrm{~A}, \Delta i=4 \mathrm{~A}$ の場合の $f$ と最大速度 $v_{\max }$ の関係を示した図 7 からも明らかな ように, 引き上げられる際の $v_{\max }$ がほほ $0.15 \mathrm{~m} / \mathrm{s}$ を 超えると液柱は分離した。また, 変動磁場と変位の位 相差 $\delta$ について整理した結果は, $\delta / \pi=0.5$ での $f$ が

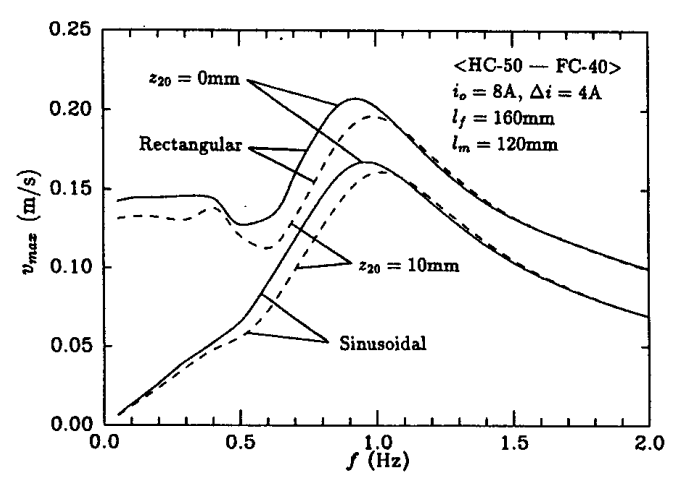

図 7 上下方向速度の最大值

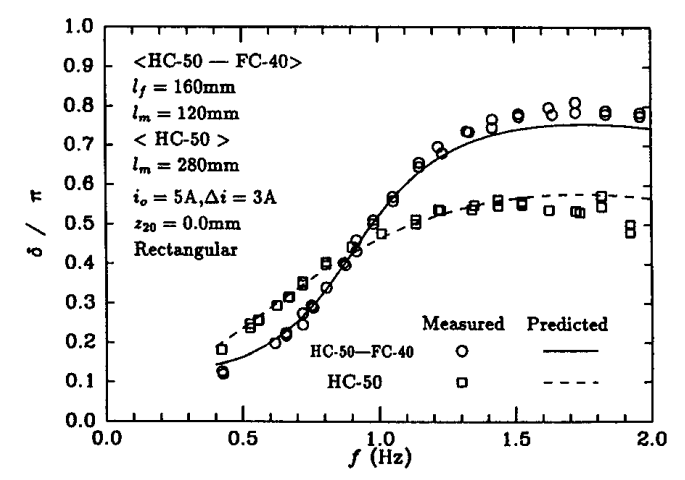

図 8 位相差 


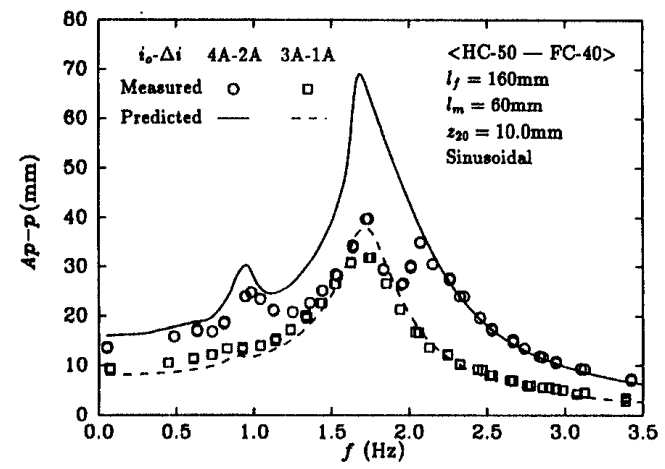

図 9 振動特性(U 字管)
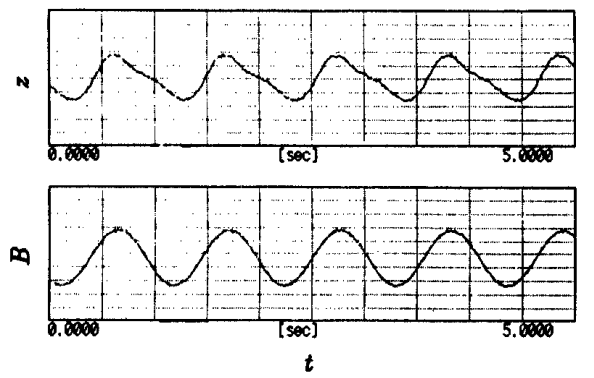

$i_{o}=3 \mathrm{~A}, \Delta i=1 \mathrm{~A}, f=1 \mathrm{~Hz}$
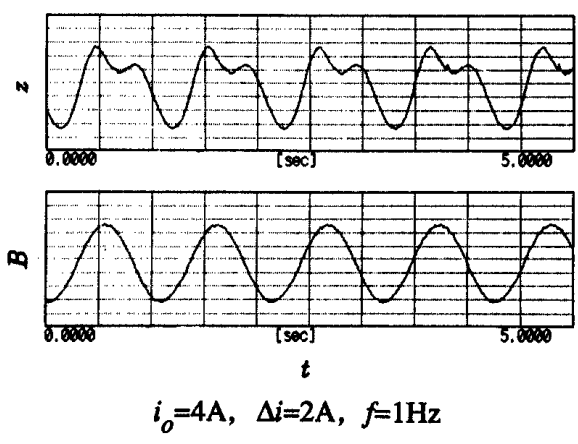

図 10 変位の時間変化

磁気力の変化が大きい $i_{o}=8 \mathrm{~A}, \Delta i=4 \mathrm{~A}$ のほうが $i_{o}=5 \mathrm{~A}, \Delta i=3 \mathrm{~A}$ の場合に比べわずかに隇少するこ とを示した.

磁性流体液柱の運動を外部に伝達するには，より低 い粘度の液体を用いるのが効果的であると考え, 本研 究でも被駆動液体には HC-50よりも粘度が低い FC40 を用いた。これによる特性の変化を検討するために, 被駆動液体部分にも HC-50を用いて測定を行った。 被駆動液体部も HC-50 の場合には, $A_{p-p}$ は小さくな り，最大変位が得られる $f$ も低下した。.また，図 8 の 方形波状変動磁場で, $i_{o}=5 \mathrm{~A}, \Delta i=3 \mathrm{~A}$ の場合の結果 にも示されるように, 位相差 $\delta$ は粘性減衰のある強制 振動における減衰比の大きな場合と同様な位相差曲線 を示した。
さらに, 装置の小形化, 省電力化の観点から, 図 1 （b）に概略を示すような管断面の変化による損失を考 慮する必要がない内径の一様な U 字管 $(d=9.8 \mathrm{~mm}$, $R=22.0 \mathrm{~mm}$ )について, 正弦波状変動磁場を印加して 検討を行った。なお，測定にはこれにあわせて小形化 したソレノイドを用い, 液柱長さ $l_{m}, l_{f}$ はそれぞれ $60,160 \mathrm{~mm}$ とした，図 9 には $z_{20}=10 \mathrm{~mm}$ の場合の $f$ に対する $A_{p-p}$ の変化を示す。このモデル管では管路 内での損失が小さいことにより, $\Delta i$ が $1 \mathrm{~A}$ と小さな 場合 $\left(i_{o}=3 \mathrm{~A}\right)$ でも比較的大きな変位が得られた. ま た，磁性流体液柱長さが短くなったことも一つの要因 であると思われるが，最大の $A_{p-p}$ が得られる $f$ も従 来のモデル管の場合のほほ 2 倍となった。さらに, $\Delta i$ を大きくして $2 \mathrm{~A}$ とした場合 $\left(i_{o}=4 \mathrm{~A}\right)$ には，最大の 変位が得られると考えられる領域で磁性流体液柱が FC-40 との界面で分離した。 さらに, 最大の変位が得 られる $f$ のほほ半分の $f$ で現れた極大值も明確にな った。加えて, 低い $f$ の領域では, 図 10 に一例を示し たように，変位の時間変化波形が乱れる傾向が見られ た。これは粘性減衰のある振動系の過渡応答における 減衰比が小さく，整定時間が長い場合の現象と類似し ている。したがって，滑らかな変位の時間変化波形を 得るためには，ある程度の適切な損失が必要である. 図 10 中に実線で示した計算結果は, $i_{0}=3 \mathrm{~A}$ で $\Delta i=1$ A の場合には定性的には測定結果と一致した。なお， この場合も計算では界面張力を一定としたが, 液柱が 界面で分離しない場合には，本数值計算により内径の 一様なU字管内での振動特性をほほ予測できるもの と考えられる。主変動磁場と変位との位相差 $\delta$ は, 共振点 $(\delta / \pi=0.5)$ 付近で $\delta$ が従来のモデル管よりも 急激に変化しており，従来のモデル管に比べ減衰比の 小さい位相差曲線の特性を示した。

\section{5. 結 論}

磁気力の変化を利用した磁性流体の運動によって駆 動される円管内液柱の運動について，実験的ならびに 理論的な検討を行った，得たる結果を要約すると次の ようになる。

（1）磁性流体を希釈することなく原液のまま用い ることにより，従来よりも大きな変位が得られたが， 条件によっては被駆動液体との界面で分離するため, 被駆動液体部に運動を効果的に伝達できない場合もあ る.

（2）この液柱の分離は磁性流体液柱が引き上げら れる際の最大速度がある值を超えると発生した。

（3）内径が一様なU字管を用いることにより， 
ソレノイドへの供給電流が小さな場合でも十分に大き な変位が得られた。しかしながら，損失が小さいため 低振動数の領域で変位の時間変化波形が乱れることか ら, 滑らかな変位波形を得るにはある程度の適切な抵 抗も必要である。

なお, 本研究は平成 5 年度文部省科学研究費補助金 (一般研究 C) の補助を受けて行われた。ここに付記し 感謝の意を表する.

$$
\text { 文献 }
$$

（1）日本機械学会編，電磁力応用機器のタイナミックス,
(1990)，63，コロナ社.

（2）小池, 機械の研究, 44-1(1992), 199.

（3）神山・Htwe, J., 小池・小山, 機論, 53-494, B(1987), 3014.

（4）佐藤・小山・小池・神山, 機論, 57-534, B(1991), 520.

（5） 小池・佐藤・青木・加川，第 2 回電磁力関連のダイナミッ クス講演論文集, (1991), 221.

（6）小池・佐藤, 機論, 59-557, B(1993), 81.

( 7) Koike, K. and Sato. A., J. Magn. Magn. Mater., 122-1 $\sim 3(1993), 217$.

（8）小池, 機論, 59-562, B(1993), 1804.

（9）日本機械学会編，技術資料管路・ダクトの流体抵抗， (1979)，69, 日本機械学会.

(10) Chantrell, R. V., Popplewell, J. and Charles, S.W., IEEE Trans. Magn. Mag., 14(1978), 975.

（11） 近江・井口, 機論, 47-418, B (1981), 993. 